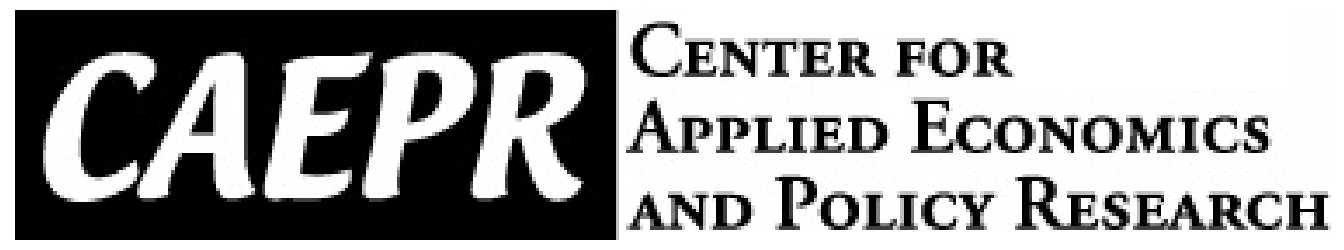

CAEPR Working Paper

\#018-2009

\title{
The Natural Resource Curse and Economic Transition
}

\author{
Michael Alexeev, Robert Conrad \\ Indiana University, Duke University
}

September 2, 2009

This paper can be downloaded without charge from the Social Science Research Network electronic library at: http://ssrn.com/abstract=1471552.

The Center for Applied Economics and Policy Research resides in the Department of Economics at Indiana University Bloomington. CAEPR can be found on the Internet at:

http://www.indiana.edu/ caepr. CAEPR can be reached via email at caepr@indiana.edu or via phone at 812-855-4050.

(C2008 by NAME. All rights reserved. Short sections of text, not to exceed two paragraphs, may be quoted without explicit permission provided that full credit, including $₫$ notice, is given to the source. 


\title{
The Natural Resource Curse and Economic Transition
}

\author{
by \\ Michael Alexeev ${ }^{*}$ and Robert Conrad ${ }^{* *}$
}

September 2009

* Corresponding author; Department of Economics, Indiana University, Bloomington, IN 47408; phone number: 812.855.7103; fax number: 812.855.3736;

e-mail: malexeev@indiana.edu

** Terry Sanford School of Public Policy and Department of Economics, Duke University, Durham, NC 27709; phone number: 919.613.7355;

e-mail: rconrad@duke.edu

We are grateful to Richard Ericson, Jim Leitzel, and the participants of 2008 American Association for the Advancement of Slavic Studies Conference Panel "Natural Resources and Transition: From Land to Oil" for insightful comments and discussion. All remaining errors and omissions are our own. 


\title{
The Natural Resource Curse and Economic Transition
}

\begin{abstract}
Using cross-country regressions, we examine the relationship between "point-source" resource abundance and economic growth, quality of institutions, investment in human and physical capital, and social welfare (life expectancy and infant mortality). Contrary to most literature, we find little evidence of natural resource curse outside of the economies in transition. In the economies in transition, there is some evidence that natural resource wealth is associated with higher infant mortality. This negative effect, however, exists only relative to other resource rich countries. Compared to other economies in transition, natural resource abundant transitional economies are not worse off with respect to our indicators.
\end{abstract}

Key words: economic transition, resource curse, institutional quality JEL Classification: P27, P28, O13, Q32 


\section{The Natural Resource Curse and Economic Transition}

\section{Introduction}

Over the last decade, a large literature has developed to investigate the relationship between natural resource wealth of a country, its economic well being and political structure. Until recently, most of this literature had argued that while the dispersed natural resources such as fertile agricultural land were generally beneficial to the economy, the so-called "point-source" resources such as oil, natural gas, and some minerals, ${ }^{1}$ often reduced long-run economic growth and the quality of the country's government and institutions, at least in developing countries. This somewhat counterintuitive effect of natural resource abundance has been called the natural resource curse or the oil curse. The more recent literature, however, has questioned the existence of this curse, pointing out serious technical problems with the empirical work that claims to demonstrate its existence. ${ }^{2}$

One intuitive reason to doubt the existence of the resource curse, particularly the detrimental effect of natural resources on most countries' institutions, is the apparent persistence of institutional quality. That is, in most countries, the quality of institutions changes only slowly and should not be radically affected by relatively recent discoveries (or recently emerged importance) of natural "point-source" resources such as oil. This argument, however, does not apply to the economies in transition where institutions have experienced radical changes in the last twenty years. One might expect, therefore, that if the curse of natural resources does exist, it would be particularly pronounced in these

\footnotetext{
${ }^{1}$ The term "point-source" resources was introduced by Isham et al. (2003).

${ }^{2}$ For a recent survey of the literature on the natural resource curse, see Rosser (2006). The most recent papers on the topic include Alexeev and Conrad (2009), Brunnschweiler (2008), and Brunnschweiler and Bulte (2008).
} 
economies. The goal of this paper is to examine the impact of natural resource endowment, and especially oil wealth, on economic growth and its factors, institutional development, and certain aspects of welfare in the economies in transition. While our overall methodology follows, with some modifications, the cross-sectional approach in Alexeev and Conrad (2009) the present paper makes two important contributions. First, it evaluates the effect of point-source resources on the economies in transition and second, it applies the analysis to a greater range of indicators and uses more recent and larger dataset than did Alexeev and Conrad (2009).

With respect to all countries, we find that the overall effect of natural resource wealth is either positive or negligible on all but one of the indicators we study. ${ }^{3}$ The lone exception is a voice and accountability measure that is negatively and significantly correlated with natural resources. There is some evidence, however, that natural resource wealth has a negative impact on the economies in transition relative to similarly endowed non-transitional economies, but this evidence is fairly weak. Our results are contrary to those of Kronenberg (2004) who claims to show that there is a "strong negative correlation between natural resource abundance and economic growth" and of Esanov et al. (2001) although the latter paper's emphasis on the progress of structural reforms is different from ours. ${ }^{4}$ Brunnschweiler (2009) also does not find any deleterious effect of

\footnotetext{
${ }^{3}$ Strictly speaking, cross-country estimation makes it difficult to determine causality. Therefore, we would normally refer to correlations rather than causal "effect." Note, however, that natural resource endowments and output of a country are largely exogenous and we control for many other relevant factors such as country's GDP and cultural and historical legacies proxied by major religions and continental dummies. These considerations suggest that even cross-country regressions are likely to reflect the strength of a causal relationship between natural resources and economic and institutional measures that we use. ${ }^{4}$ Kronenberg's results are suspect, however, because his regressions include only the economies in transition and, therefore, his conclusions are based on 19 observations. Moreover, Kronenberg uses the share of primary goods in total exports as a measure of natural resource abundance. This measure is highly problematic because a country whose economy functions poorly for any reason would have little to export but natural resources. Therefore, share of primary goods in exports may be negatively related to economic
} 
oil on economic growth in transitional economies. In fact, using a panel of 27 economies in transition, she finds a rather strong positive link between oil wealth and growth. ${ }^{5}$

Our paper differs from all of the above papers at least in three important respects. First, rather than limiting our sample to the economies in transition, we perform our estimation based on a large cross-section of countries, using dummy variables (both by themselves and in interaction with natural resource wealth) for the economies in transition. Second, we estimate the relationship between natural resources and not only economic growth, but also with the countries' institutions, investments in physical and human capital, and such indicators of welfare as life expectancy and infant mortality. Third, by estimating our cross-sectional regressions separately for two different years, we do not restrict our regression coefficients to remain the same over the period of transition. In addition, we employ a greater variety of measures of natural resource wealth than any of the above papers.

The paper is organized as follows. The next section describes our estimation approach and the data. Section 3 presents the results and Section 4 concludes.

\section{Estimation approach and the data}

Our basic approach to determine the impact of natural resource wealth on the economies in transition is fairly straightforward. We estimate the following regression based on cross-sectional data:

\footnotetext{
growth for reasons unrelated to do with natural resource endowment. See Stijns (2006) for a discussion of natural resource endowment measures and their implications for testing for the natural resource curse.

${ }^{5}$ While panel analysis has certain advantages, it also creates potential estimation problems that are difficult to resolve. Fixed effects estimation is difficult to use because of relatively little variation over time in many relevant variables. Random effects, on the other hand, require rather strong assumption that the unobserved individual heterogeneity is uncorrelated with the included regressors. Both methods usually assume that there are no structural changes (beyond possibly those that can be reflected in a time fixed effect) in the estimated relationship over the period of estimation. This last assumption may be particularly problematic for an economy in transition. In addition, if growth rates are autocorrelated, the resulting panel estimates would be biased unless appropriated adjustments are made.
} 


$$
Y_{i}=b_{0}+b_{1} G D P_{i}+b X_{i}+b_{2} T R_{i}+b_{3} C I S_{i}+b_{4} N_{i}+b_{5} T R_{i} \cdot N_{i}+e_{i}
$$

where $i$ is a country index (it is dropped in the discussion below), $Y$ is an indicator of the country's development, the impact on which of natural resources we are trying to establish, GDP is per capita GDP in purchasing power parity terms, $T R$ is a dummy variable that equals unity if the economy is in transition from socialism to markets, CIS is a dummy variable for the countries belonging to the Commonwealth of Independent States, $N$ is an indicator of natural resource endowment, and $X$ is a vector of other controls. (The list of the economies in transition and the CIS countries, including the oil producers, is provided in corresponding dummy variable descriptions in Table 1.)

We estimate regression (1) for several different dependent variables and for two different years, 1996 (or either 1995 or 2000, depending on data availability) and 2005. The choice of 1996 is dictated by the fact that this is the first year for which World Bank institutional quality indicators are available. Regressions with school enrollment as dependent variables use year 2000 instead of 1996 because of relatively poor data availability for years prior to 2000. (The two different base years for the regressions are also notable in that the 1995-2000 period was preceded by several years of relatively low oil prices while oil prices were high and increasing during 2000-2005 period.) Our dependent variables include growth of per capita GDP between 1996 and 2005, institutional quality indicators (rule of law, corruption control, and voice and accountability) ${ }^{6}$, factors of economic growth (measures of investment in physical capital and human capital) and demographic welfare indicators (life expectancy, infant mortality). A more detailed description of these and other measures we use as well as our sources for these data are provided in Table 1 .

\footnotetext{
${ }^{6}$ The precise meaning of these indicators is described in Kaufmann, et al. (2008).
} 
All of our regressions are estimated for two different measures of point-source resource abundance. One measure is the logarithm of one plus per capita value of oil output in the country. The value of oil output is calculated by multiplying the number of barrels of oil produced by the world price of oil in 2007 US dollars. No adjustment is made for oil quality or cost of extraction. The other measure is the logarithm of one plus the amount of non-renewable energy and mineral resources extracted by the country as a percentage of gross national income (GNI). While the first measure is much narrower than the second one, it has two significant advantages. First, it focuses on the ultimate "point-source" resource (oil) and second, it is independent of the country's level of economic development. This latter property is particularly important. Measures of natural resource abundance expressed as shares of GDP (or GNI) may produce biased results, because countries that have low GDP for reasons unrelated to their natural resource endowment would also have large natural resource-to-GDP ratios. Therefore, it might seem that the low GDP and other problems related to low GDP are the result of large natural resource wealth while in reality it is the low GDP that causes natural resource wealth to appear to be high. (Although our resource measures are based on output, we sometimes refer to resource wealth or abundance, because stock and flow measures are highly correlated in the case of oil and mineral resources. For example, proven oil reserves and annual oil output had a coefficient of correlation of about 0.75 in 2008.)

One of our most important control variables is per capita GDP in purchasing power parity terms. While this variable is likely to have an important impact on most of the dependent variables that we study, its use also creates significant estimation difficulties. First, most of our dependent variables are likely to influence per capita GDP, 
causing simultaneity problems. Some authors attempt to alleviate this problem by using earlier year GDP data (e.g., using 1970 GDP in year 2000 cross-country regressions). This approach does not solve the simultaneity problem, however, because GDP data for different years are highly correlated. In addition, the use of much earlier GDP data as controls in our regressions is problematic, because the pre-1989 GDP data for most economies in transition are quite unreliable. For our purposes, perhaps even a more important problem with using per capita GDP as a control variable is that it is correlated with natural resource endowment. That is, countries rich in oil and other natural resources tend to have higher GDP per capita. Because of this, regressions where dependent variables are positively correlated with GDP (e.g., institutional quality regressions) may produce estimates biased in favor of the natural resource curse. As Alexeev and Conrad (2009) explained, "[a]ccording to their GDP, natural resource rich countries should have good institutions. Because their institutions are poor relative to industrialized countries with similar GDP levels (i.e., they are at the level where they would have been if the country had no oil) the regression assigns a negative coefficient to the measure of oil wealth." In reality, however, such outcomes imply that high GDP that resulted mostly from oil wealth simply does not improve institutional quality rather than makes it worse, as suggested by the oil curse literature.

In order to solve or at least alleviate we instrument GDP via these geographical variables. Valid (excluded) instruments for per capita GDP should be important exogenous determinants of per capita GDP and should not affect the dependent variable, except via per capita GDP. It is this latter requirement that makes finding good instruments a difficult task in our case. We use overidentification tests to select valid 
instruments among the basic set of geographic variables (country's latitude, European population dummy, Latin American dummy, and South East Asia dummy) used for a similar purpose by Alexeev and Conrad (2009). We recognize that this is a somewhat formalistic approach, but it is better than not instrumenting per capita GDP at all.

In the conventional instrumental variables approach, per capita GDP is regressed in the first stage on both the excluded instruments and the other independent variables (included instruments). Then, the value of per capita GDP predicted in the first stage regression is used in the second stage. The overall effect of an independent variable such as natural resource abundance measure on the dependent variable would then combine its first-stage effect on per capita GDP and its second stage coefficient. For example, if the first stage coefficient of variable $X$ is $\alpha$, the second stage coefficient of $X$ is $\beta$, and the second stage coefficient of per capita GDP is $\gamma$, then the point estimate of the combined effect of $X$ on the dependent variable would be $\pi=\alpha \gamma+\beta$. It is important to keep in mind this point when interpreting the results below. In particular, it will be useful to remember that for the economy in transition dummy variable the first stage coefficient, $\alpha$, is negative and for natural resource wealth $\alpha>0$.

We are interested in estimating the overall effect, $\pi$, of natural resources on our dependent variables. A disadvantage of combining point estimates of the coefficients from two stages of instrumental regressions is that we do not obtain a standard error of this estimate. For this reason, we prefer to use a two-step procedure, according to which we first calculate predicted value of per capita GDP using the excluded instruments and those included instruments whose overall effect on our dependent variables is not the 
focus of our paper. In the second step, we use this predicted value of per capita GDP as one of the regressors together with all our included instruments.

For example, in our growth rates regressions, we first determine the predicted values of the logarithm of per capita GDP for 1996 from the following regression:

$$
\begin{aligned}
& \hat{\mathrm{Y}}_{1996}=7.7+1.1 \cdot \mathrm{LAT}+1.4 \cdot \mathrm{EUR}+1.1 \cdot \mathrm{LATAM}+.9 \cdot \mathrm{EAST}-1.1 \cdot \mathrm{ETHN}+.01 \cdot P R T S+.01 \cdot \mathrm{MSLM} \\
& \begin{array}{llllllll}
(.4) & (.75) & (.31) & (.22) & (.43) & (.41) & (.00) & (.00)
\end{array} \\
& \text { Adjusted } \mathrm{R}^{2}=0.45 \\
& \text { Observations }=153
\end{aligned}
$$

where LAT stands for absolute latitude of the country, and EUR, LATAM, and EAST are dummy variables for the European population, Latin and Central America, and South East Asia, ETHN denotes the index of ethnolinguistic decentralization, and PRTS and MSLM are shares of Protestants and Muslims in the country, respectively. Then, we regress per capita GDP growth rates for 1996-2005 on $\hat{\mathrm{Y}}_{1996}$, and our other independent variables, including TR, CIS, $N$, and an interaction term TR. $N$, but excluding $L A T, E U R$, LATAM, and EAST. Of particular interest in this second regression are estimates of the coefficients of the variables related to economic transition and to natural resources.

Due to the use of a generated regressor, standard errors produced by OLS are biased (see Pagan, 1984) and adjusting for this bias is quite difficult. For this reason we base our inferences on bootsrapped standard errors. ${ }^{7}$

We select our control variables based on what has been used in the literature on economic growth and on institutional quality (e.g., ethnic heterogeneity and share of Protestants in the country's population have been shown to correlate, respectively,

\footnotetext{
${ }^{7}$ This approach extends the procedure used by Alexeev and Conrad (2009) by adding regressors at the first stage and using bootstrapped errors in the second stage.
} 
positively and negatively with the degree of corruption in a country; see, Treisman, 2000). After using a number of different specifications, we settled on the variables that are truly exogenous with respect to our dependent variables and that are statistically significant in most of our regressions. For example, we use the share of Protestants and of Muslims, but not the share of Catholics, because the latter variable was usually not statistically significant. We stress also, that no control variables that we tried had a significant effect on the estimates that we focus on in this paper.

As long as we use per capita GDP predicted from (2) and similar regressions for other years, our OLS regressions are not likely to suffer from simultaneity problems. ${ }^{8}$

\section{Results}

In this section we present the results of our regressions and discuss briefly their implications. We present both the conventional 2SLS regressions and the corresponding OLS regressions with predicted per capita GDP as one of the regressors. In addition, we present a few OLS regressions with actual per capita GDP as a regressor in order to illustrate the potential for misleading results when this specification is used.

\subsection{Economic growth regressions}

We begin by estimating regression (1) with growth rate of GDP as a dependent variable. Specifically, we use the logarithm of growth of per capita purchasing power parity GDP between 1996 and 2005 (i.e., logarithm of the ratio of per capita GDP in 2005 and in 1996). The only explanatory variables that are consistently statistically significant in either the second stage of instrumental variable regressions or OLS regressions are the

\footnotetext{
${ }^{8}$ Measures of oil and minerals output might be somewhat endogenous to economic growth and the quality of institutions, but this endogeneity is most likely rather weak, except when per capita GDP is in the denominator. However, in this latter case, the endogeneity would act to increase the negative effect of natural resources on economic performance and institutional quality. Since we do not observe such negative effect in most of our regressions, this potential endogeneity only makes our results stronger.
} 
transition economy dummy variable and the CIS dummy variable. Both of these have positive coefficients in all regressions. Neither per capita oil output nor the share of energy and mineral rents in GDP are statistically significant in any of the regressions either by themselves or in interaction with the transition dummies. That is, natural resource wealth does not appear to have affected economic growth in countries around the world between 1996 and 2005. The institutional quality variables are not statistically significant either. Note that we use actual rather than predicted values of per capita 1996 GDP as one of the controls in OLS regressions. This is because the use of predicted values does not change qualitative results of these regressions. We also note that using predicted values of corruption control in OLS regressions in a manner similar to the use of predicted value of per capita GDP does not affect the results. The instruments in the instrumental variable estimation appear to be strong and easily pass the overidentification tests. Table 3 presents the results with only the coefficients of the variables of greatest interest shown. These results are contrary to Kronenberg's (2004) but are consistent with Brunnschweiler (2009).

\subsection{Institutional quality regressions}

While relatively recent growth rates in the economies in transition and elsewhere do not seem to be affected by natural resource wealth, there is a possibility that longer term economic development could be affected by the curse, because the abundance of point-source resources might be detrimental to the country's institutions that would in turn have a negative effect of growth rates in the future. This argument might be particularly important in the economies in transition, because their institutions have been experiencing dramatic changes during the transition period. 
To examine whether institutional quality is correlated with natural resource abundance, we run regressions (1) with three different measures of institutional quality (rule of law, control of corruption, and voice and accountability) as dependent variables for 1996 and for 2005. As explained before, the fact that per capita GDP levels are likely to be affected by both the institutional quality and natural resources makes the use of per capita GDP as a control variable problematic. Instead, we employ values of this variable predicted from regressions (2). However, for the sake of comparison, we also present some of the regressions where actual values of per capita GDP are used. The results are shown in Tables 5 and 6 . The instrumental variables regressions that produce very similar point estimates of our coefficients of interest (via combining the first and second stage coefficients, $\pi=\alpha \gamma+\beta$, as described in Section 2 above) for these and other regressions are available upon request.

The contrast between OLS regression estimates with actual and predicted values of per capita GDP underlines the importance of the use of the latter variable. When actual GDP is used, natural resources have a highly statistically significant negative coefficient while in the rule of law and corruption control regressions with predicted per capita GDP the coefficient is usually positive and in one case even significant at $10 \%$ level. In the voice and accountability regression, however, the coefficient of natural resource variable remains negative and statistically significant even with predicted per capita GDP values. (We present the results with the actual per capita GDP variable only for the rule of law regression. All other institutional quality regressions that use actual per capita GDP follow the same pattern.) 
More important for the purposes of the present paper is that the coefficient of the interaction between natural resource abundance and transition economy dummy while often negative is not statistically significant in any of the institutional quality regressions that use predicted value of per capita GDP as an independent variable. This result does not support the notion of a more or less significant natural resource curse with respect to institutional development either in general or in the economies in transition.

Note that the dummy variable for the economies in transition is negative and highly statistically significant in these regressions. This is not particularly surprising, of course, because institutions in these economies are still developing. The CIS dummy variable is negative, but not statistically significant, suggesting that controlling for other factors, the CIS members do not have worse institutions than the other economies in transition.

\subsection{Physical and human capital regressions}

Next we examine the relationship between natural resource endowment and the non-institutional factors determining economic growth: investment in physical and human capital. Most regressions (1) with gross capital formation as a dependent variable do not produce statistically significant coefficients for any of our variables of interest and we do not present them here. ${ }^{9}$ Human capital regressions produce somewhat more interesting results. We use net primary and secondary school enrollment rates in years 2000 and 2005 (the World Bank’s WDI Online database has more or less comprehensive school enrollment data only starting in 1999). As Tables 7-8 show, natural resource measures generally have positive and significant (both statistically and numerically)

\footnotetext{
${ }^{9}$ The only exceptions are the positive and highly significant coefficient of the transition economy dummy variable in the 2005 regressions and a marginally significant positive coefficient of natural resource measure in one of the 1996 regressions.
} 
effect on primary and secondary school enrollments, ${ }^{10}$ but there is evidence that this effect is weaker or even absent in the economies in transition. This is implied by the fact that in all specifications, the coefficients of the interaction between natural resources and the transition dummy are negative and most are sufficiently close by absolute value to the coefficients of non-interacted natural resource measure, so that the combined point estimate of the effect of natural resources on human capital investment for the economies in transition is about zero. Interestingly, the CIS countries have statistically significantly greater enrollments in secondary schools both in the 2000 and 2005 regressions and in primary schools in the 2000 regressions.

\subsection{Social welfare regressions}

Finally, we run regressions (1) with dependent variables representing two different social welfare indicators: life expectancy and infant mortality for under five years of age. The results are presented in Tables 9-10. Unlike in the human capital accumulation regressions, economic transition (but not natural resources) appears to be associated with worse demographic outcomes, albeit rather weakly. The coefficients of the economic transition dummy variable are always negative for life expectancy and positive for infant mortality, although they are not always statistically significant in the life expectancy regressions. ${ }^{11}$ The relatively low life expectancy in some of the economies in transition has been addressed in several studies (e.g., Cornia and Paniccià, 2000, and Brainerd, 1998) but no consensus with respect to its causes seems to have emerged.

\footnotetext{
${ }^{10}$ Note that our results with respect to the effect of natural resource abundance on investment and on human capital in the non-transition economies are contrary to those obtained by Gylfason (2001) and Gylfason and Zoega (2002). The difference is due to our use of predicted values of per capita GDP. ${ }^{11}$ We use 1995 instead of 1996 in these regressions, because WDI Online has the data for a significantly greater number of countries in 1995 than in 1996.
} 
The coefficients of the natural resource measures on the other hand are always positive for life expectancy and negative for infant mortality although they are not statistically significant in the 2005 regressions. The interaction terms between economic transition and natural resources have opposite signs and are close by absolute value to the corresponding coefficients of natural resource measures, implying that for the economies in transition, natural resource abundance might not have the beneficial effect that it has in other economies, but there is no implication of a detrimental effect relative to other economies in transition.

\section{Conclusions}

Using cross-sectional regression approach, we examine the relationship between "point-source" resource abundance and economic growth, quality of institutions, investment in human and physical capital, and such measures of social welfare as life expectancy and infant mortality. Contrary to much of the existing literature, we find no significant evidence of natural resource curse outside of the economies in transition with respect to all but one measure we investigate. The only exception is a negative correlation between oil and natural resources in general and the voice and accountability measure. In the economies in transition, natural resource abundance seems to have had some detrimental effect on infant mortality. However, the negative effect of natural resources in this case is barely statistically significant and appears simply to offset the positive effect of natural resources in other resource rich countries, implying that the net effect of natural resource endowments on this indicator in the economies in transition is insignificant. 


\section{References}

Alesina, Alberto, Arnaud Devleeschauwer, William Easterly, Sergio Kurlat, and Romain Wacziarg, 2003. "Fractionalization," Journal of Economic Growth 8(2): 155-194.

Alexeev, Michael, and Robert Conrad, 2009. "The Elusive Curse of Oil," Review of Economics and Statistics, forthcoming.

Brainerd, Elizabeth, 1998. "Market reform and mortality in transition economies," World Development, 26(11):2013-2027.

Brunnschweiler, Christa, 2008. "Cursing the Blessings? Natural Resource Abundance, Institutions, and Economic Growth," World Development, 36(3):399-419.

$09 / 108$. , 2009. "Oil and Growth in Transition Countries," CER-ETH, Working Paper , and Erwin Bulte, 2008. "The resource curse revisited and revised: A tale of paradoxes and red herrings," Journal of Environmental Economics and Management, 55(3):248-264.

Cornia, G. A., and R. Paniccià, 2000. The Mortality Crisis in Transitional Economics. Oxford University Press.

Esanov, Akram, Martin Raiser, and Willem Buiter, 2001. "Nature's Blessing or Nature's Curse: the Political Economy of Transition in Resource-based Economies," EBRD Working Paper No 65, November.

Gylfason, Thorvaldur, 2001. "Natural resources, education, and economic development," European Economic Review 45:847-859. , and Gylfi Zoega, 2002a. "Natural Resource and Economic Growth: The Role of Investment," mimeo.

Isham, J., M. Woolcock, L. Pritchett, and G. Busby 2003. "The Variety of Resource Experience: How Natural Resource Export Structures Affect the Political Economy of Economic Growth," Middlebury College Economics Discussion Paper No. 03-08R.

Iwaskiw, Walter R., ed. Lithuania: A Country Study. Washington: GPO for the Library of Congress, 1995.

Kaufmann, Daniel, Aart Kraay, and Massimo Mastruzzi, 2008. "Governance Matters VII: Aggregate and Individual Governance Indicators 1996-2007," World Bank Policy Research Working Paper 4654, June. 
Kronenberg, Tobias, 2004. "The curse of natural resources in the transition economies," The Economics of Transition, 12(3):399-426.

La Porta, Rafael, Florencio Lopez-de-Silanes, Andrei Shleifer, and Robert Vishny, 1999. "The Quality of Government," Journal of Law, Economics, \& Organization 15(1): 222279.

Pagan, Adrian, 1984. "Econometric Issues in the Analysis of Regressions with Generated Regressors," International Economic Review, 25(1): 221-247.

Rosser, Andrew, 2006. "The Political Economy of the Resource Curse: A Literature Survey," IDS Working Paper 268.

Stijns, J-P, 2006. "Natural Resource Abundance and Human Capital Accumulation," World Development 34(6):1060-83.

Treisman, Daniel, 2000. "The causes of corruption: a cross-national study," Journal of Public Economics, 76:399-457

WDI Online, 2009. World Development Indicators Online Database. World Bank website. http://www.worldbank.org/data/onlinedatabases/onlinedatabases.html. 


\section{APPENDIX}

Table 1. Data description and sources

\begin{tabular}{|c|c|}
\hline Variable & Description and Source \\
\hline CIS & $\begin{array}{l}\text { A dummy variable that equals unity if the country is a former Soviet } \\
\text { republic that is a member of the Commonwealth of Independent States, and } \\
\text { has a value of zero otherwise. Countries of the CIS: Armenia, Azerbaijan, } \\
\text { Belarus, Georgia, Kazakhstan, Kyrgyzstan, Moldova, Russian Federation, } \\
\text { Tajikistan, Turkmenistan, Ukraine, Uzbekistan; oil-producing countries are } \\
\text { underlined }\end{array}$ \\
\hline $\begin{array}{l}\text { Corruption } \\
\text { Control }\end{array}$ & $\begin{array}{l}\text { The "control over corruption" index for the respective year (the year is } \\
\text { either indicated explicitly or corresponds to the year in table/column } \\
\text { heading). The index is intended to measure "perceptions of the extent to } \\
\text { which public power is exercised for private gain, including both petty and } \\
\text { grand forms of corruption, as well as "capture" of the state by elites and } \\
\text { private interests." Higher values indicate lower corruption. Source: } \\
\text { Kaufmann et al. (2008). }\end{array}$ \\
\hline $\begin{array}{l}\text { Economy in } \\
\text { transition }\end{array}$ & $\begin{array}{l}\text { A dummy variable that equals unity if the country is an economy in } \\
\text { transition from socialism to markets, and is zero otherwise. Economies in } \\
\text { transition: Albania, Bulgaria, China, Czech Republic, Estonia, Croatia, } \\
\text { Hungary, Cambodia, Lithuania, Latvia, Macedonia, Mongolia, Poland, } \\
\text { Romania, Serbia/Montenegro, Slovak Republic, Slovenia, Vietnam as well } \\
\text { as all CIS countries (see CIS entry above); oil-producing countries are } \\
\text { underlined }\end{array}$ \\
\hline $\begin{array}{l}\text { Ethnolinguistic } \\
\text { Fractionalization }\end{array}$ & $\begin{array}{l}\text { An index of ethnolinguistic fractionalization computed as one minus the } \\
\text { Herfindahl index of ethnic group shares. The definition of ethnicity here } \\
\text { involves a combination of racial and linguistic characteristics. Source: } \\
\text { Alesina et al. (2003) }\end{array}$ \\
\hline $\begin{array}{l}\text { European } \\
\text { population }\end{array}$ & $\begin{array}{l}\text { A dummy variable that has a value of one for countries with predominantly } \\
\text { European population, and zero otherwise. }\end{array}$ \\
\hline Growth of GDP & $\begin{array}{l}\text { Logarithm of the ratio of per capita GDP in purchasing power parity terms } \\
\text { for years } 2005 \text { and } 1996 \text {. Source: WDI Online (2008). }\end{array}$ \\
\hline $\begin{array}{l}\text { Infant mortality } \\
\text { rate }\end{array}$ & $\begin{array}{l}\text { Logarithm of the number of children dying before the age of } 5 \text { per } 1000 \\
\text { births. Source: WDI Online (2008). }\end{array}$ \\
\hline $\begin{array}{l}\text { Life expectancy at } \\
\text { birth }\end{array}$ & $\begin{array}{l}\text { Logarithm of life expectancy at birth measured in years. Source: WDI } \\
\text { Online (2008). }\end{array}$ \\
\hline $\begin{array}{l}\text { Muslim } \\
\text { population share }\end{array}$ & Share of Muslim population in the country. Source: La Porta, et al. (1999). \\
\hline $\begin{array}{l}\text { Per capita GDP } \\
\text { (actual) }\end{array}$ & $\begin{array}{l}\text { Logarithm of per capita PPP GDP for the respective year (the year is either } \\
\text { indicated explicitly or corresponds to the year in table/column heading) in } \\
\text { constant } 2005 \text { international dollars. Source: WDI Online (2008). }\end{array}$ \\
\hline $\begin{array}{l}\text { Per capita GDP } \\
\text { (predicted) }\end{array}$ & $\begin{array}{l}\text { Values predicted from regressions (2) and (3), Section } 2 \text { of the present } \\
\text { paper. }\end{array}$ \\
\hline $\begin{array}{l}\text { Per capita oil } \\
\text { output }\end{array}$ & $\begin{array}{l}\text { Logarithm of one plus the value (at world market price in } 2007 \text { US\$) of } \\
\text { country's per capita oil output for the respective year (the year is either } \\
\text { indicated explicitly or corresponds to the year in table/column heading). Oil } \\
\text { output and world market price are from BP Statistical Review (2008) } \\
\text { available at http://www.bp.com/statisticalreview }\end{array}$ \\
\hline
\end{tabular}




\begin{tabular}{|c|c|}
\hline $\begin{array}{l}\text { Primary school } \\
\text { enrollment }\end{array}$ & $\begin{array}{l}\text { The number of children enrolled in primary school that belong to the age } \\
\text { group that officially corresponds to primary schooling, expressed as a } \\
\text { percentage of the total population in the same age group. Source: WDI } \\
\text { Online (2008). }\end{array}$ \\
\hline $\begin{array}{l}\text { Protestant } \\
\text { population share }\end{array}$ & $\begin{array}{l}\text { Share of Protestant population in the country. Source: La Porta, et al. } \\
\text { (1999). The number for Lithuania is from Iwaskiw (1995). }\end{array}$ \\
\hline $\begin{array}{l}\text { Quality of } \\
\text { regulations }\end{array}$ & $\begin{array}{l}\text { The "regulatory quality" index for the respective year (the year is either } \\
\text { indicated explicitly or corresponds to the year in table/column heading). The } \\
\text { index is intended to measure "perceptions of the ability of the government to } \\
\text { formulate and implement sound policies and regulations that permit and } \\
\text { promote private sector development." Source: Kaufmann et al. (2008). }\end{array}$ \\
\hline $\begin{array}{l}\text { Resource } \\
\text { depletion/GNI }\end{array}$ & $\begin{array}{l}\text { Logarithm of one plus depletion of the country's energy and mineral } \\
\text { resources as a share of gross national income for the respective year (the } \\
\text { year is either indicated explicitly or corresponds to the year in table/column } \\
\text { heading). Source: WDI Online (2008). }\end{array}$ \\
\hline Rule of Law & $\begin{array}{l}\text { The "rule of law" index for the respective year (the year is either indicated } \\
\text { explicitly or corresponds to the year in table/column heading). The index is } \\
\text { intended to measure "perceptions of the extent to which agents have } \\
\text { confidence in and abide by the rules of society, and in particular the quality } \\
\text { of contract enforcement, property rights, the police, and the courts, as well } \\
\text { as the likelihood of crime and violence. Source: Kaufmann et al. (2008). }\end{array}$ \\
\hline $\begin{array}{l}\text { Secondary school } \\
\text { enrollment }\end{array}$ & $\begin{array}{l}\text { The number of children enrolled in secondary school that belong to the age } \\
\text { group that officially corresponds to secondary schooling, expressed as a } \\
\text { percentage of the total population in the same age group. Source: WDI } \\
\text { Online (2008). }\end{array}$ \\
\hline $\begin{array}{l}\text { Voice and } \\
\text { accountability }\end{array}$ & $\begin{array}{l}\text { The "voice and accountability" index for the respective year (the year is } \\
\text { either indicated explicitly or corresponds to the year in table/column } \\
\text { heading). The index is intended to measure "perceptions of the extent to } \\
\text { which a country's citizens are able to participate in selecting their } \\
\text { government, as well as freedom of expression, freedom of association, and a } \\
\text { free media." Source: Kaufmann et al. (2008). }\end{array}$ \\
\hline
\end{tabular}


Table 2. Descriptive statistics of the main variables of interest

\begin{tabular}{|c|c|c|c|c|c|c|c|c|c|}
\hline \multirow[t]{2}{*}{ Variable } & \multicolumn{3}{|c|}{ Entire sample } & \multicolumn{3}{|c|}{$\begin{array}{l}\text { Economies in } \\
\text { transition }\end{array}$} & \multicolumn{3}{|c|}{ CIS } \\
\hline & Obs. & Mean & STD & Obs. & Mean & STD & Obs. & Mean & STD \\
\hline Corruption Control, 1996 & 139 & .032 & 1.01 & 28 & -.378 & .641 & 12 & -.915 & .365 \\
\hline Corruption Control, 2005 & 154 & -.044 & 1.02 & 27 & -.379 & .635 & 11 & -.855 & .193 \\
\hline Growth of GDP & 153 & .241 & .260 & 28 & .479 & .186 & 11 & .552 & .196 \\
\hline Infant mortality rate, 1995 & 148 & 73.6 & 71.0 & 27 & 40.6 & 32.3 & 11 & 53.9 & 30.6 \\
\hline Infant mortality rate, 2005 & 153 & 59.2 & 66.3 & 27 & 26.3 & 23.4 & 11 & 37.5 & 23.6 \\
\hline $\begin{array}{l}\text { Life expectancy at birth, } \\
1995\end{array}$ & 154 & 65.3 & 10.5 & 27 & 68.5 & 3.75 & 12 & 66.9 & 2.38 \\
\hline $\begin{array}{l}\text { Life expectancy at birth, } \\
2005\end{array}$ & 154 & 67.3 & 11.3 & 28 & 70.4 & 4.36 & 12 & 67.9 & 2.66 \\
\hline $\begin{array}{l}\text { Log of Per capita GDP, } \\
1996\end{array}$ & 156 & 9238 & 064 & 28 & 5603 & 4460 & 11 & 2793 & 2031 \\
\hline $\begin{array}{l}\text { Log of Per capita GDP, } \\
2005\end{array}$ & 159 & 12030 & 14095 & 29 & 8679 & 6144 & 11 & 4933 & 3417 \\
\hline Per capita oil output, 1996 & 154 & 373.9 & 1503 & 28 & 48.5 & 107.5 & 12 & 103.7 & 148.7 \\
\hline Per cap & & & & & & & & & \\
\hline $\begin{array}{l}\text { Primary school } \\
\text { enrollment, } 2000\end{array}$ & 117 & 83.1 & 17.9 & 18 & 90.8 & 4.81 & 6 & 87.4 & 5.13 \\
\hline $\begin{array}{l}\text { Primary school } \\
\text { enrollment, } 2005\end{array}$ & 119 & 88.0 & 13.0 & 22 & 90.8 & 4.39 & 9 & 88.5 & 5.26 \\
\hline $\begin{array}{l}\text { Resource depletion/GNI, } \\
1996\end{array}$ & 150 & 5.17 & 10.3 & 27 & 5.57 & 9.77 & 11 & 10.5 & 13.8 \\
\hline $\begin{array}{l}\text { Resource depletion/GNI, } \\
2005\end{array}$ & 145 & 9.66 & 18.5 & 27 & 11.0 & 20.8 & 11 & 22.2 & 29.2 \\
\hline Rule of Law, 1996 & 150 & .054 & .999 & 27 & -.332 & .580 & 11 & -.794 & .313 \\
\hline Rule of Law, 2005 & 154 & -.068 & .999 & 27 & -.340 & 647 & 11 & -.85 & .245 \\
\hline $\begin{array}{l}\text { Secondary school } \\
\text { enrollment, } 2000\end{array}$ & 109 & 60.5 & 27.5 & 20 & 75.7 & 17.1 & 7 & 78.0 & 8.46 \\
\hline $\begin{array}{l}\text { Secondary school } \\
\text { enrollment, } 2005\end{array}$ & 98 & 66.3 & 26.6 & 19 & 81.6 & 14.8 & 9 & 82.4 & 4.30 \\
\hline $\begin{array}{l}\text { Voice and accountability, } \\
1996\end{array}$ & 153 & -.026 & .954 & 27 & -.233 & .796 & 11 & -.768 & .429 \\
\hline $\begin{array}{l}\text { Voice and accountability, } \\
2005\end{array}$ & 154 & $\begin{array}{l}.078 \\
\end{array}$ & .965 & 27 & -.206 & 1.00 & 11 & -.955 & .510 \\
\hline
\end{tabular}

Note: Descriptive statistics are for the maximum number of countries that were used in the regressions 
Table 3. GDP growth regressions (IV GMM specifications)

Dependent variable: Logarithm of the ratio of per capita purchasing power parity GDP for 2005 and 1996

\begin{tabular}{|c|c|c|c|c|c|c|c|c|}
\hline & $\begin{array}{c}1^{\text {st }} \text { stage } \\
\text { (per } \\
\text { capita } \\
\text { GDP) }\end{array}$ & $\begin{array}{l}2 \mathrm{~d} \\
\text { stage }\end{array}$ & $\begin{array}{l}1^{\text {st }} \text { stage } \\
\text { (Corr. } \\
\text { control) }\end{array}$ & $\begin{array}{c}2 \mathrm{~d} \\
\text { stage }\end{array}$ & $\begin{array}{c}1^{\text {st }} \text { stage } \\
\text { (per } \\
\text { capita } \\
\text { GDP) }\end{array}$ & $\begin{array}{c}2 \mathrm{~d} \\
\text { stage }\end{array}$ & $\begin{array}{c}1^{\text {st }} \text { stage } \\
\text { (Corr. } \\
\text { control) }\end{array}$ & $\begin{array}{c}2 \mathrm{~d} \\
\text { stage }\end{array}$ \\
\hline Variable name & (1) & (2) & (3) & (4) & $(5)$ & (6) & (7) & (8) \\
\hline Per capita GDP, 1996 & - & $\begin{array}{l}.014 \\
(.028)\end{array}$ & - & $\begin{array}{l}-.039 \\
(.044)\end{array}$ & - & $\begin{array}{c}.021 \\
(.024)\end{array}$ & - & $\begin{array}{l}.025 \\
(.037)\end{array}$ \\
\hline $\begin{array}{l}\text { Corruption control, } \\
1996\end{array}$ & - & - & - & $\begin{array}{c}.074 \\
(.048)\end{array}$ & - & - & - & $\begin{array}{l}.013 \\
(.047)\end{array}$ \\
\hline Transition economy & $\begin{array}{l}-.917 * * * \\
(.204)\end{array}$ & $\begin{array}{l}.193 * * * \\
(.051)\end{array}$ & $\begin{array}{c}-1.17 * * * \\
(.184)\end{array}$ & $\begin{array}{c}.252 * * * \\
(.049)\end{array}$ & $\begin{array}{c}-1.13 * * * \\
(.211)\end{array}$ & $\begin{array}{c}.193 * * * \\
(.059)\end{array}$ & $\begin{array}{c}-1.26 * * * \\
(.194)\end{array}$ & $\begin{array}{l}.184 * * \\
(.065)\end{array}$ \\
\hline CIS & $\begin{array}{l}-.382 \\
(.250)\end{array}$ & $\begin{array}{l}.155^{* *} \\
(.071)\end{array}$ & $\begin{array}{l}-.386 \\
(.239)\end{array}$ & $\begin{array}{l}.125^{*} \\
(.072)\end{array}$ & $\begin{array}{l}-.256 \\
(.271)\end{array}$ & $\begin{array}{l}.171^{* *} \\
(.069)\end{array}$ & $\begin{array}{l}-.411^{*} \\
(.244)\end{array}$ & $\begin{array}{l}.139^{*} \\
(.071)\end{array}$ \\
\hline $\begin{array}{l}\text { Per capita oil output, } \\
1996\end{array}$ & $\begin{array}{c}.174 * * * \\
(.030)\end{array}$ & $\begin{array}{l}.005 \\
(.010)\end{array}$ & $\begin{array}{c}.014 \\
(.020)\end{array}$ & $\begin{array}{l}.003 \\
(.008)\end{array}$ & - & - & - & - \\
\hline $\begin{array}{l}\text { Transition*PC oil } \\
\text { output, } 1996\end{array}$ & $\begin{array}{c}-.140 * * \\
(.063)\end{array}$ & $\begin{array}{l}.010 \\
(.020)\end{array}$ & $\begin{array}{c}.009 \\
(.044)\end{array}$ & $\begin{array}{l}.012 \\
(.019)\end{array}$ & - & - & - & - \\
\hline $\begin{array}{l}\text { Resource } \\
\text { depletion/GDP, } 1996\end{array}$ & - & - & - & - & $\begin{array}{c}.419 * * * \\
(.071)\end{array}$ & $\begin{array}{c}.026 \\
(.027)\end{array}$ & $\begin{array}{l}-.012 \\
(.052)\end{array}$ & $\begin{array}{l}-.008 \\
(.023)\end{array}$ \\
\hline $\begin{array}{l}\text { Transition*Resource } \\
\text { depletion/GDP, } 1996\end{array}$ & - & - & - & - & $\begin{array}{c}-.355^{* * * *} \\
(.128)\end{array}$ & $\begin{array}{l}-.004 \\
(.044)\end{array}$ & $\begin{array}{c}.050 \\
(.098)\end{array}$ & $\begin{array}{c}.047 \\
(.043)\end{array}$ \\
\hline Centered R-squared & .670 & .192 & .644 & .360 & .695 & .226 & .660 & .409 \\
\hline $\begin{array}{l}\text { F-statistic for excl. } \\
\text { instruments (p-value) }\end{array}$ & $\begin{array}{l}25.97 \\
(.000)\end{array}$ & - & $\begin{array}{l}49.24 \\
(.000)\end{array}$ & - & $\begin{array}{l}36.42 \\
(.000)\end{array}$ & - & $\begin{array}{l}42.77 \\
(.000)\end{array}$ & - \\
\hline Hansen J (p-value) & - & .600 & - & .180 & - & .625 & - & .172 \\
\hline Observations & 153 & 153 & 137 & 137 & 150 & 150 & 134 & 134 \\
\hline
\end{tabular}

Notes:

Robust standard errors are in parentheses;

Constant term and some of the independent variables coefficients (LAT, EUR, LATAM, EAST, MSLM, PRTS) are not shown;

*** - significant at $1 \%$ level; $* *$ - significant at $5 \%$ level; * - significant at $10 \%$ level;

Excluded instruments: LAT, EUR, LATAM, EAST

$1^{\text {st }}$ stage regressions for per capita GDP in the specification with corruption control are very similar to the $1^{\text {st }}$ stage regressions in Column 1 and 5, respectively, although they are not identical due to the different number of observations in these regressions. 
Table 4. GDP growth regressions (OLS)

Dependent variable: Logarithm of the ratio of per capita purchasing power parity GDP for 2005 and 1996

\begin{tabular}{|l|c|c|c|c|}
\hline Variable name & $(1)$ & $(2)$ & $(3)$ & $(4)$ \\
\hline Per capita GDP, 1996 & .022 & -.010 & .031 & -.006 \\
(predicted) & $(.032)$ & $(.037)$ & $(.036)$ & $(.032)$ \\
\hline Corruption control, 1996 & - & .016 & - & $.034^{*}$ \\
& $.189^{* * *}$ & $\begin{array}{c}.234^{* * *} \\
(.058)\end{array}$ & $\begin{array}{c}.186^{* *} \\
(.078)\end{array}$ & $\begin{array}{c}.247^{* * *} \\
(.059)\end{array}$ \\
\hline Transition economy & $.151^{* *}$ & $.137^{*}$ & .157 & $.146^{* *}$ \\
& $(.073)$ & $(.070)$ & $(.100)$ & $(.074)$ \\
\hline CIS & .007 & -.002 & - & - \\
\hline Per capita oil output, 1996 & $(.012)$ & $(.006)$ & - & - \\
\hline Transition*PC oil output, & .006 & .011 & - & - \\
1996 & $(.027)$ & $(.019)$ & -030 & .004 \\
\hline Resource depletion/GDP, & - & - & $(.039)$ & $(.018)$ \\
1996 & - & - & -.007 & .009 \\
\hline Transition*Resource & -162 & .320 & .196 & $.038)$ \\
depletion/GDP, 1996 & 153 & 137 & 150 & 134 \\
\hline Adjusted R-squared & & & & \\
\hline Observations & & & & \\
\hline
\end{tabular}

Notes:

Bootstrapped standard errors with 50 replications are in parentheses;

Constant term and some of the control variable coefficients (the share of Muslims and of Protestants in the population, and the index of ethnolinguistic fractionalization) are not shown;

*** - significant at $1 \%$ level; $* *$ - significant at $5 \%$ level; $*$ - significant at $10 \%$ level. 
Table 5. Institutional quality regressions with per capita oil output value, 1996 and 2005 (OLS)

Dependent variables: Measures of institutional quality for 1996 and 2005

\begin{tabular}{|l|c|c|c|c|c|c|c|}
\hline \multicolumn{1}{|c|}{ Variable name } & \multicolumn{9}{|c|}{$\begin{array}{c}\text { Rule of } \\
\text { law }\end{array}$} & $\begin{array}{c}\text { Rule of } \\
\text { law }\end{array}$ & $\begin{array}{c}\text { Corr. } \\
\text { control }\end{array}$ & $\begin{array}{c}\text { Voice \& } \\
\text { account. }\end{array}$ & $\begin{array}{c}\text { Rule of } \\
\text { law }\end{array}$ & $\begin{array}{c}\text { Corr. } \\
\text { control }\end{array}$ & $\begin{array}{c}\text { Voice \& } \\
\text { account. }\end{array}$ \\
\hline & $(1)$ & $(2)$ & $(3)$ & $(4)$ & $(5)$ & $(6)$ & $(7)$ \\
\hline $\begin{array}{l}\text { Per capita GDP, } \\
\text { predicted }\end{array}$ & - & $.737^{* * *}$ & $.647^{* *}$ & .251 & $.731^{* * *}$ & $.777^{* * *}$ & .197 \\
$(.261)$ & $(.267)$ & $(.255)$ & $(.241)$ & $(.232)$ & $(.267)$ \\
\hline Per capita GDP, & $.550^{* * *}$ & - & - & - & - & - & - \\
actual & $(.046)$ & - & - & - & - & - & - \\
\hline Transition & $-.533^{* * *}$ & $-1.01^{* * *}$ & $-1.08^{* * *}$ & $-.702^{* * *}$ & $-.974^{* * *}$ & $-1.09^{* * *}$ & $-.443^{* *}$ \\
economy & $(.168)$ & $(.196)$ & $(.212)$ & $(.200)$ & $(.207)$ & $(.162)$ & $(.178)$ \\
\hline CIS & -.032 & -.069 & -.145 & -.060 & -.231 & -.145 & -.427 \\
& $(.202)$ & $(.274)$ & $(.251)$ & $(.278)$ & $(.266)$ & $(.222)$ & $(.370)$ \\
\hline Per capita oil & $-.055^{* * *}$ & $.038^{*}$ & .007 & $-.032^{*}$ & .001 & .001 & $-.053^{* * *}$ \\
output & $(.020)$ & $.020)$ & $(.020)$ & $(.017)$ & $(.018)$ & $(.019)$ & $. .018)$ \\
\hline Transition*PC oil & .006 & -.080 & -.015 & -.015 & -.038 & -.042 & -.016 \\
output & $(.042)$ & $(.072)$ & $(.059)$ & $(.055)$ & $(.045)$ & $(.052)$ & $(.069)$ \\
\hline R-squared & .766 & .577 & .587 & .567 & .595 & .607 & .576 \\
\hline Observations & 150 & 150 & 137 & 153 & 154 & 154 & 154 \\
\hline
\end{tabular}

Notes:

Robust standard errors (bootstrapped standard errors with 50 replications in OLS regressions with predicted per capita GDP) are in parentheses;

Constant term and some of the independent variables coefficients (LAT, EUR, LATAM, EAST, MSLM, PRTS) are not shown;

*** - significant at $1 \%$ level; ** - significant at $5 \%$ level; * - significant at $10 \%$ level;

Independent variables are measured for the same years as dependent variables 
Table 6. Institutional quality regressions with share of resource depletion in GNI, 1996 and 2005 (OLS)

Dependent variables: Measures of institutional quality for 1996 and 2005

\begin{tabular}{|l|c|c|c|c|c|c|c|}
\hline & \multicolumn{9}{|c|}{1996} & \multicolumn{2}{c|}{2005} \\
\hline \multicolumn{1}{|c|}{ Variable name } & $\begin{array}{c}\text { Rule of } \\
\text { law }\end{array}$ & $\begin{array}{c}\text { Rule of } \\
\text { law }\end{array}$ & $\begin{array}{c}\text { Corr. } \\
\text { control }\end{array}$ & $\begin{array}{c}\text { Voice \& } \\
\text { account. }\end{array}$ & $\begin{array}{c}\text { Rule of } \\
\text { law }\end{array}$ & $\begin{array}{c}\text { Corr. } \\
\text { control }\end{array}$ & $\begin{array}{c}\text { Voice \& } \\
\text { account. }\end{array}$ \\
\hline & $(1)$ & $(2)$ & $(3)$ & $(4)$ & $(5)$ & $(6)$ & $(7)$ \\
\hline $\begin{array}{l}\text { Per capita GDP, } \\
\text { predicted }\end{array}$ & - & $.896^{* * *}$ & $.769^{* *}$ & .376 & $.782^{* * *}$ & $.812^{* * *}$ & .310 \\
$(.292)$ & $(.311)$ & $(.250)$ & $(.236)$ & $(.220)$ & $(.252)$ \\
\hline Per capita GDP, & $.571^{* * *}$ & - & - & - & - & - & - \\
actual & $(.048)$ & - & - & - & - & - & - \\
\hline Transition economy & $-.520^{* * *}$ & $-1.14^{* * *}$ & $-1.20^{* * *}$ & $-.739^{* * *}$ & $-.973^{* * *}$ & $-1.10^{* * *}$ & $-.414^{* *}$ \\
& $(.146)$ & $(.192)$ & $(.264)$ & $(.193)$ & $(.190)$ & $(.215)$ & $(.165)$ \\
\hline CIS & -.144 & -.107 & -.195 & -.116 & -.191 & -.095 & -.466 \\
& $(.232)$ & $(.307)$ & $(.255)$ & $(.332)$ & $(.278)$ & $(.246)$ & $(.357)$ \\
\hline Resource & $-.207 * * *$ & .037 & -.027 & $-.120^{* *}$ & -.037 & -.022 & $-.122^{* * *}$ \\
depletion/GNI & $(.050)$ & $(.061)$ & $(.048)$ & $(.060)$ & $(.048)$ & $(.031)$ & $(.043)$ \\
\hline Transition* & .169 & -.028 & .077 & .071 & -.004 & -.018 & .018 \\
Resource & $(.110)$ & $(.156)$ & $(.108)$ & $(.158)$ & $(113)$ & $(.110)$ & $(.115)$ \\
depletion/GNI & & & & & & & .604 \\
\hline R-squared & .776 & .588 & .603 & .588 & .648 & .661 & .602 \\
\hline Observations & 147 & 147 & 134 & 150 & 144 & 144 & 144 \\
\hline
\end{tabular}

Notes:

Robust standard errors (bootstrapped standard errors with 50 replications in OLS regressions with predicted per capita GDP) are in parentheses;

Constant term and some of the independent variables coefficients (LAT, EUR, LATAM, EAST, MSLM, PRTS) are not shown;

*** - significant at $1 \%$ level; ** - significant at $5 \%$ level; * - significant at $10 \%$ level;

Independent variables are measured for the same years as dependent variables 
Table 7. Human capital investment regressions with per capita oil output value, 2000 and 2005 (OLS)

Dependent variables: Logarithm of primary school enrollment, \% net; logarithm of secondary school enrollment, \% net, 2000 and 2005

\begin{tabular}{|l|c|c|c|c|c|c|}
\hline \multicolumn{1}{|c|}{ Variable name } & \multicolumn{9}{|c|}{2000} & \multicolumn{2}{c|}{2005} \\
\hline & $\begin{array}{c}\text { Prim. } \\
\text { school }\end{array}$ & $\begin{array}{c}\text { Prim. } \\
\text { school }\end{array}$ & $\begin{array}{c}\text { Sec. } \\
\text { school }\end{array}$ & $\begin{array}{c}\text { Sec. } \\
\text { school }\end{array}$ & $\begin{array}{c}\text { Prim. } \\
\text { school }\end{array}$ & $\begin{array}{c}\text { Sec. } \\
\text { school }\end{array}$ \\
\hline Per capita GDP, & $(1)$ & $(2)$ & $(3)$ & $(4)$ & $(5)$ & $(6)$ \\
predicted & - & $\begin{array}{c}.265^{* * *} \\
(.054)\end{array}$ & - & $\begin{array}{c}.402^{* * *} \\
(.102)\end{array}$ & $\begin{array}{c}.163^{* * *} \\
(.034)\end{array}$ & $\begin{array}{c}.360^{* * *} \\
(.087)\end{array}$ \\
\hline Per capita GDP, actual & $.124^{* * *}$ & - & $.421^{* * *}$ & - & - & - \\
& $(.026)$ & $-.048)$ & - & - & - \\
\hline Transition economy & $.160^{* * *}$ & .038 & $.462^{* * *}$ & .099 & -.026 & .051 \\
& $(.047)$ & $(.039)$ & $(.115)$ & $(.173)$ & $(.022)$ & $(.202)$ \\
\hline CIS & $.167^{* *}$ & $.142^{* *}$ & $.575^{* * *}$ & $.448^{* * *}$ & .005 & $.349^{* *}$ \\
& $(.081)$ & $(.070)$ & $(.107)$ & $(.156)$ & $(.033)$ & $(.177)$ \\
\hline Per capita oil output & .009 & $.017^{* *}$ & -.009 & $.053^{* *}$ & $.011^{* *}$ & $.042^{* * *}$ \\
& $(.007)$ & $(.007)$ & $(.011)$ & $(.020)$ & $(.005)$ & $(.015)$ \\
\hline Transition*PC oil & $-.021^{*}$ & $-.020^{*}$ & -.017 & -.036 & -.009 & -.029 \\
output & $(.013)$ & $.011)$ & $(.027)$ & $(.041)$ & $(.007)$ & $(.029)$ \\
\hline R-squared & .542 & .476 & .762 & .530 & .356 & .463 \\
\hline Observations & 111 & 111 & 101 & 101 & 119 & 98 \\
\hline
\end{tabular}

Notes:

Robust standard errors (bootstrapped standard errors with 50 replications in OLS regressions with predicted per capita GDP) are in parentheses;

Constant term and some of the independent variables coefficients (LAT, EUR, LATAM, EAST, MSLM, PRTS) are not shown;

*** - significant at $1 \%$ level; $* *$ - significant at $5 \%$ level; $*$ - significant at $10 \%$ level;

Independent variables are measured for the same years as dependent variables 
Table 8. Human capital investment regressions with share of resource depletion in GNI, , 2000 and 2005 (OLS)

Dependent variables: Logarithm of primary school enrollment, \% net; logarithm of secondary school enrollment, \% net, 2000 and 2005

\begin{tabular}{|c|c|c|c|c|c|c|}
\hline \multirow{3}{*}{ Variable name } & \multicolumn{3}{|c|}{2000} & & \multicolumn{2}{|c|}{2005} \\
\hline & $\begin{array}{l}\text { Prim. } \\
\text { school }\end{array}$ & $\begin{array}{l}\text { Prim. } \\
\text { school }\end{array}$ & $\begin{array}{c}\text { Sec. } \\
\text { school }\end{array}$ & $\begin{array}{c}\text { Sec. } \\
\text { school }\end{array}$ & $\begin{array}{l}\text { Prim. } \\
\text { school }\end{array}$ & $\begin{array}{c}\text { Sec. } \\
\text { school }\end{array}$ \\
\hline & (1) & (2) & (3) & (4) & (5) & (6) \\
\hline Per capita GDP, predicted & - & $\begin{array}{l}.233^{* * *} \\
(.063)\end{array}$ & - & $\begin{array}{l}.233^{* * *} \\
(.063)\end{array}$ & $\begin{array}{l}.133^{* * * *} \\
(.036)\end{array}$ & $\begin{array}{l}.386^{* * * *} \\
(.087)\end{array}$ \\
\hline Per capita GDP, actual & $\begin{array}{c}.123^{* * * *} \\
(.024)\end{array}$ & - & $\begin{array}{l}.416^{* * * *} \\
(.048)\end{array}$ & - & - & - \\
\hline Transition economy & $\begin{array}{c}.185^{* * *} \\
(.052)\end{array}$ & $\begin{array}{l}.037 \\
(.051)\end{array}$ & $\begin{array}{l}.481 * * * \\
(.121)\end{array}$ & $\begin{array}{l}.037 \\
(.051)\end{array}$ & $\begin{array}{l}.008 \\
(.037)\end{array}$ & $\begin{array}{l}-.021 \\
(.152)\end{array}$ \\
\hline CIS & $\begin{array}{l}.182 * * \\
(.086)\end{array}$ & $\begin{array}{l}.175^{*} \\
(.093)\end{array}$ & $\begin{array}{l}.557 * * * \\
(.103)\end{array}$ & $\begin{array}{l}.175^{*} \\
(.093)\end{array}$ & $\begin{array}{l}.051 \\
(.057)\end{array}$ & $\begin{array}{l}.404 * * \\
(.170)\end{array}$ \\
\hline Resource depletion/GNI & $\begin{array}{l}.040^{*} \\
(.022)\end{array}$ & $\begin{array}{l}.060 * * \\
(.023)\end{array}$ & $\begin{array}{l}.009 \\
(.035) \\
\end{array}$ & $\begin{array}{l}.060^{* *} \\
(.023)\end{array}$ & $\begin{array}{l}.041^{* *} \\
(.019) \\
\end{array}$ & $\begin{array}{l}.100 * * \\
(.047)\end{array}$ \\
\hline $\begin{array}{l}\text { Transition* Resource } \\
\text { depletion/GNI }\end{array}$ & $\begin{array}{c}-.061^{* *} \\
(.029)\end{array}$ & $\begin{array}{l}-.055 \\
(.038)\end{array}$ & $\begin{array}{l}-.027 \\
(.063)\end{array}$ & $\begin{array}{l}-.055 \\
(.038)\end{array}$ & $\begin{array}{l}-.036 \\
(.027)\end{array}$ & $\begin{array}{l}-.004 \\
(.079)\end{array}$ \\
\hline R-squared & .576 & .501 & .768 & .501 & .395 & .532 \\
\hline Observations & 110 & 110 & 100 & 110 & 90 & 90 \\
\hline
\end{tabular}

Notes:

Robust standard errors (bootstrapped standard errors with 50 replications in OLS regressions with predicted per capita GDP) are in parentheses;

Constant term and some of the independent variables coefficients (LAT, EUR, LATAM, EAST, MSLM, PRTS) are not shown;

*** - significant at $1 \%$ level; ** - significant at 5\% level; * - significant at $10 \%$ level;

Independent variables are measured for the same years as dependent variables 
Table 9. Life expectancy and infant mortality regressions with per capita oil output value, 1995 and 2005 (OLS)

Dependent variables: Logarithm of life expectancy at birth, total (years); logarithm of infant mortality rate, under-5 (per 1000 births), 1995 and 2005

\begin{tabular}{|c|c|c|c|c|c|c|}
\hline \multirow[b]{2}{*}{ Variable name } & \multicolumn{4}{|c|}{1995} & \multicolumn{2}{|c|}{2005} \\
\hline & $\begin{array}{c}\text { Life } \\
\text { expect. }\end{array}$ & $\begin{array}{c}\text { Life } \\
\text { expect. }\end{array}$ & $\begin{array}{c}\text { Infant } \\
\text { mortality }\end{array}$ & $\begin{array}{c}\text { Infant } \\
\text { mortality }\end{array}$ & $\begin{array}{c}\text { Life } \\
\text { expect. }\end{array}$ & $\begin{array}{c}\text { Infant } \\
\text { mortality }\end{array}$ \\
\hline & (1) & (2) & (3) & (4) & (5) & (6) \\
\hline $\begin{array}{l}\text { Per capita GDP, } \\
\text { predicted }\end{array}$ & - & $\begin{array}{c}.136^{* * *} \\
(.022)\end{array}$ & - & $\begin{array}{c}-.626^{* * *} \\
(.133)\end{array}$ & $\begin{array}{c}.150 * * * \\
(.020)\end{array}$ & $\begin{array}{c}-.841 * * * \\
(.139)\end{array}$ \\
\hline $\begin{array}{l}\text { Per capita GDP, } \\
\text { actual }\end{array}$ & $\begin{array}{c}.108^{* * * *} \\
(.010)\end{array}$ & - & $\begin{array}{c}-.680 * * * \\
(.044)\end{array}$ & 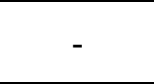 & - & - \\
\hline Transition economy & $\begin{array}{c}.066 * * * \\
(.021) \\
\end{array}$ & $\begin{array}{l}-.035 \\
(.025) \\
\end{array}$ & $\begin{array}{l}.052 \\
(.103) \\
\end{array}$ & $\begin{array}{l}.456^{* *} \\
(.180)\end{array}$ & $\begin{array}{c}-.046^{* *} \\
(.023) \\
\end{array}$ & $\begin{array}{l}.405 * * \\
(.157)\end{array}$ \\
\hline CIS & $\begin{array}{c}.077^{* * * *} \\
(.025)\end{array}$ & $\begin{array}{l}.069 \\
(.042)\end{array}$ & $\begin{array}{c}-.392 * * * \\
(.122)\end{array}$ & $\begin{array}{l}-.264 \\
(.250)\end{array}$ & $\begin{array}{c}.026 \\
(.043) \\
\end{array}$ & $\begin{array}{l}-.060 \\
(.295)\end{array}$ \\
\hline Per capita oil output & $\begin{array}{c}-.008^{* *} \\
.003\end{array}$ & $\begin{array}{c}.011 * * * \\
(.004)\end{array}$ & $\begin{array}{l}.046^{* *} \\
(.018)\end{array}$ & $\begin{array}{c}-.078 * * * \\
(.026)\end{array}$ & $\begin{array}{l}.005 \\
(.004)\end{array}$ & $\begin{array}{l}-.037 \\
(.023)\end{array}$ \\
\hline $\begin{array}{l}\text { Transition*PC oil } \\
\text { output }\end{array}$ & $\begin{array}{l}-.006 \\
(.009)\end{array}$ & $\begin{array}{l}-.021 \\
(.013)\end{array}$ & $\begin{array}{l}.037 \\
(.032)\end{array}$ & $\begin{array}{l}.142 * * \\
(.064)\end{array}$ & $\begin{array}{l}-.016 \\
(.013) \\
\end{array}$ & $\begin{array}{l}.100 \\
(.072)\end{array}$ \\
\hline R-squared & .762 & .551 & .891 & .686 & .594 & .673 \\
\hline Observations & 153 & 153 & 148 & 148 & 154 & 153 \\
\hline
\end{tabular}

Notes:

Robust standard errors (bootstrapped standard errors with 50 replications in OLS regressions with predicted per capita GDP) are in parentheses;

Constant term and some of the independent variables coefficients (LAT, EUR, LATAM, EAST, MSLM, PRTS) are not shown;

*** - significant at $1 \%$ level; $* *$ - significant at $5 \%$ level; $*$ - significant at $10 \%$ level;

Independent variables are measured for the same years as dependent variable 
Table 10. Life expectancy and infant mortality regressions with share of resource depletion in GNI, 1995 and 2005 (OLS)

Dependent variables: Logarithm of life expectancy at birth, total (years); logarithm of infant mortality rate, under-5 (per 1000 births), 1995 and 2005

\begin{tabular}{|c|c|c|c|c|c|c|}
\hline \multirow[b]{2}{*}{ Variable name } & \multicolumn{4}{|c|}{1995} & \multicolumn{2}{|c|}{2005} \\
\hline & $\begin{array}{c}\text { Life } \\
\text { expect. }\end{array}$ & $\begin{array}{c}\text { Life } \\
\text { expect. }\end{array}$ & $\begin{array}{c}\text { Infant } \\
\text { mortality }\end{array}$ & $\begin{array}{c}\text { Infant } \\
\text { mortality }\end{array}$ & $\begin{array}{c}\text { Life } \\
\text { expect. }\end{array}$ & $\begin{array}{c}\text { Infant } \\
\text { mortality }\end{array}$ \\
\hline & (4) & (5) & (6) & (7) & (4) & (6) \\
\hline $\begin{array}{l}\text { Per capita GDP, } \\
\text { predicted }\end{array}$ & - & $\begin{array}{c}.145^{* * *} \\
(.023)\end{array}$ & - & $\begin{array}{c}-.646^{* * *} \\
(.148) \\
\end{array}$ & $\begin{array}{c}.154 * * * \\
(.024)\end{array}$ & $\begin{array}{c}-.897 * * * \\
(.144)\end{array}$ \\
\hline Per capita GDP, actual & $\begin{array}{c}.110^{* * * *} \\
(.010)\end{array}$ & - & $\begin{array}{c}-.704 * * * \\
(.045)\end{array}$ & - & - & - \\
\hline Transition economy & $\begin{array}{c}.070 * * * \\
(.022) \\
\end{array}$ & $\begin{array}{c}-.053^{*} \\
(.028) \\
\end{array}$ & $\begin{array}{l}-.081 \\
(.127)\end{array}$ & $\begin{array}{l}.502 * * \\
(.205) \\
\end{array}$ & $\begin{array}{l}-.048 \\
(.033) \\
\end{array}$ & $\begin{array}{l}.429 * \\
(.239) \\
\end{array}$ \\
\hline CIS & $\begin{array}{l}.062 * * \\
(.029)\end{array}$ & $\begin{array}{l}.068^{* *} \\
(.034)\end{array}$ & $\begin{array}{c}-.336^{* * *} \\
(.113)\end{array}$ & $\begin{array}{l}-.306 \\
(.247)\end{array}$ & $\begin{array}{c}.033 \\
(.065) \\
\end{array}$ & $\begin{array}{l}-.151 \\
(.223)\end{array}$ \\
\hline Resource depletion/GNI & $\begin{array}{c}-.022 * * \\
(.009) \\
\end{array}$ & $\begin{array}{l}.024^{*} \\
(.012) \\
\end{array}$ & $\begin{array}{l}.127 * * * \\
(.046)\end{array}$ & $\begin{array}{c}-.154 * * \\
(.073) \\
\end{array}$ & $\begin{array}{l}.010 \\
(.009) \\
\end{array}$ & $\begin{array}{l}-.058 \\
(.038) \\
\end{array}$ \\
\hline $\begin{array}{l}\text { Transition* Resource } \\
\text { depletion/GNI }\end{array}$ & $\begin{array}{l}.009 \\
(.018)\end{array}$ & $\begin{array}{c}-.025 \\
(.031) \\
\end{array}$ & $\begin{array}{c}.024 \\
(.068) \\
\end{array}$ & $\begin{array}{l}.238^{*} \\
(.140)\end{array}$ & $\begin{array}{l}-.019 \\
(.031) \\
\end{array}$ & $\begin{array}{l}.120 \\
(.117)\end{array}$ \\
\hline R-squared & .760 & .533 & .893 & 681 & 618 & .729 \\
\hline Observations & 150 & 150 & 145 & 145 & 145 & 144 \\
\hline
\end{tabular}

Notes:

Robust standard errors (bootstrapped standard errors with 50 replications in OLS regressions with predicted per capita GDP) are in parentheses;

Constant term and some of the independent variables coefficients (LAT, EUR, LATAM, EAST, MSLM, PRTS) are not shown;

*** - significant at $1 \%$ level; $* *$ - significant at $5 \%$ level; * - significant at $10 \%$ level;

Independent variables are measured for the same years as dependent variable 


\section{Appendix: IV GMM Regressions}

Table 1A. Institutional quality regressions with per capita oil output value (second stages of IV GMM estimation)

Dependent variables: Measures of institutional quality for 1996 and 2005

\begin{tabular}{|c|c|c|c|c|c|c|c|}
\hline & \multicolumn{3}{|c|}{1996} & \multicolumn{4}{|c|}{2005} \\
\hline & 2d stage & 2d stage & $2 \mathrm{~d}$ stage & $1^{\text {st }}$ stage & 2d stage & $2 d$ stage & $2 \mathrm{~d}$ stage \\
\hline Variable name & $\begin{array}{c}\text { Rule of } \\
\text { law }\end{array}$ & $\begin{array}{l}\text { Corr. } \\
\text { control }\end{array}$ & $\begin{array}{l}\text { Voice \& } \\
\text { account. }\end{array}$ & $\begin{array}{l}\text { GDP per } \\
\text { capita }\end{array}$ & $\begin{array}{l}\text { Rule of } \\
\text { law }\end{array}$ & $\begin{array}{l}\text { Corr. } \\
\text { control }\end{array}$ & $\begin{array}{l}\text { Voice \& } \\
\text { account. }\end{array}$ \\
\hline & (1) & (2) & (3) & (4) & (5) & (6) & (7) \\
\hline Per capita GDP & $\begin{array}{l}.676^{* * * *} \\
(.139)\end{array}$ & $\begin{array}{c}.766 * * * \\
(.197)\end{array}$ & $\begin{array}{l}.611^{* * * *} \\
(.068)\end{array}$ & - & $\begin{array}{c}.667 * * * \\
(.107)\end{array}$ & $\begin{array}{c}.713 * * * \\
(.121)\end{array}$ & $\begin{array}{l}.596 * * * \\
(.063)\end{array}$ \\
\hline Transition economy & $\begin{array}{c}-.445^{* *} \\
(.192)\end{array}$ & $\begin{array}{l}-.424^{*} \\
(.256)\end{array}$ & $\begin{array}{l}-.221 \\
(.137)\end{array}$ & $\begin{array}{c}-.750 * * * \\
(.189)\end{array}$ & $\begin{array}{c}-.516 * * * \\
(.117)\end{array}$ & $\begin{array}{c}-.591 * * * \\
(.126)\end{array}$ & $\begin{array}{l}-.050 \\
(.106)\end{array}$ \\
\hline CIS & $\begin{array}{l}-.019 \\
(.194)\end{array}$ & $\begin{array}{l}-.058 \\
(.228)\end{array}$ & $\begin{array}{l}-.071 \\
(.199)\end{array}$ & $\begin{array}{l}-.314 \\
(.265)\end{array}$ & $\begin{array}{l}-.177 \\
(.172)\end{array}$ & $\begin{array}{l}-.098 \\
(.156)\end{array}$ & $\begin{array}{l}-.590^{* *} \\
(.237)\end{array}$ \\
\hline $\begin{array}{l}\text { Per capita oil } \\
\text { output }\end{array}$ & $\begin{array}{c}-.078^{* *} \\
(.032)\end{array}$ & $\begin{array}{c}-.124 * * * \\
(.049)\end{array}$ & $\begin{array}{c}-.131 * * * \\
(.024)\end{array}$ & $\begin{array}{c}.148 * * * \\
(.027)\end{array}$ & $\begin{array}{c}-.093 * * * \\
(.024)\end{array}$ & $\begin{array}{c}-.097 * * * \\
(.029)\end{array}$ & $\begin{array}{c}-.134 * * * \\
(.024)\end{array}$ \\
\hline $\begin{array}{l}\text { Transition*PC oil } \\
\text { output }\end{array}$ & $\begin{array}{l}.021 \\
(.043)\end{array}$ & $\begin{array}{l}.091^{*} \\
(.055)\end{array}$ & $\begin{array}{l}.076^{*} \\
(.044)\end{array}$ & $\begin{array}{c}-.119 * * \\
(.056)\end{array}$ & $\begin{array}{l}.047 \\
(.034)\end{array}$ & $\begin{array}{c}.044 \\
(.036)\end{array}$ & $\begin{array}{l}.069^{*} \\
(.039)\end{array}$ \\
\hline R-squared & .771 & .687 & .681 & .643 & .807 & .783 & .625 \\
\hline $\begin{array}{l}\text { F-statistic for } \\
\text { excluded } \\
\text { instruments } \\
\text { (p-value) }\end{array}$ & - & - & - & $\begin{array}{l}14.37 \\
(.000)\end{array}$ & - & - & - \\
\hline Hansen J (p-value) & .864 & .487 & .944 & - & .432 & .304 & .329 \\
\hline Observations & 150 & 137 & 153 & 154 & 154 & 154 & 154 \\
\hline
\end{tabular}

Notes:

robust standard errors are in parentheses;

constant term and some of the independent variables coefficients (LAT, EUR, LATAM, EAST, MSLM, PRTS) are not shown;

*** - significant at $1 \%$ level; ** - significant at $5 \%$ level; * - significant at $10 \%$ level;

Excluded instruments: LAT, EAST (for Rule of law and Control of corruption); LAT, EUR (for Voice and accountability);

$1^{\text {st }}$ stage regressions for 1996 are not shown here because they are very similar to $1^{\text {st }}$ stage regressions for per capita GDP (column (1) in Table 3), although they are not identical due to the different number of observations in the regressions; $1^{\text {st }}$ stage regressions for 2005 are the same for all institutional variables;

Independent variables are measured for the same years as dependent variables 
Table 2A. Institutional quality regressions with share of resource depletion in GNI, 1996 and 2005 (IV GMM estimation)

Dependent variables: Measures of institutional quality for 1996 and 2005

\begin{tabular}{|c|c|c|c|c|c|c|c|}
\hline & \multicolumn{3}{|c|}{1996} & \multicolumn{4}{|c|}{2005} \\
\hline & 2d stage & 2d stage & $2 \mathrm{~d}$ stage & $1^{\text {st }}$ stage & 2d stage & 2d stage & 2d stage \\
\hline Variable name & $\begin{array}{c}\text { Rule of } \\
\text { law }\end{array}$ & $\begin{array}{l}\text { Corr. } \\
\text { control }\end{array}$ & $\begin{array}{l}\text { Voice \& } \\
\text { account. }\end{array}$ & $\begin{array}{c}\text { GDP per } \\
\text { capita }\end{array}$ & $\begin{array}{l}\text { Rule of } \\
\text { law }\end{array}$ & $\begin{array}{l}\text { Corr. } \\
\text { control }\end{array}$ & $\begin{array}{l}\text { Voice \& } \\
\text { account. }\end{array}$ \\
\hline & (1) & (2) & (3) & (4) & (5) & (6) & (7) \\
\hline Per capita GDP & $\begin{array}{c}.621 * * * \\
(.101)\end{array}$ & $\begin{array}{l}.651^{* * *} \\
(.137)\end{array}$ & $\begin{array}{l}.529 * * * \\
(.058)\end{array}$ & - & $\begin{array}{c}.632 * * * \\
(.090)\end{array}$ & $\begin{array}{c}.658 * * * \\
(.099)\end{array}$ & $\begin{array}{l}.560 * * * \\
(.058)\end{array}$ \\
\hline Transition economy & $\begin{array}{c}-.474 * * * \\
(.164)\end{array}$ & $\begin{array}{l}-.476^{* *} \\
(.223)\end{array}$ & $\begin{array}{l}-.194 \\
(.130) \\
\end{array}$ & $\begin{array}{c}-.834 * * * \\
(.198) \\
\end{array}$ & $\begin{array}{c}-.485 * * * \\
(.113) \\
\end{array}$ & $\begin{array}{c}-.591 * * * \\
(.130)\end{array}$ & $\begin{array}{l}-.000 \\
(.111)\end{array}$ \\
\hline CIS & $\begin{array}{l}-.165 \\
(.209)\end{array}$ & $\begin{array}{l}-.167 \\
(.234)\end{array}$ & $\begin{array}{l}-.185 \\
(.192)\end{array}$ & $\begin{array}{l}-.084 \\
(.296)\end{array}$ & $\begin{array}{l}-.251 \\
(.170)\end{array}$ & $\begin{array}{l}-.158 \\
(.143)\end{array}$ & $\begin{array}{c}-.692 * * * \\
(.220)\end{array}$ \\
\hline $\begin{array}{l}\text { Resource } \\
\text { depletion/GNI }\end{array}$ & $\begin{array}{c}-.227 * * * \\
(.061)\end{array}$ & $\begin{array}{c}-.308 * * * \\
(.077)\end{array}$ & $\begin{array}{c}-.326^{* * * *} \\
(.051)\end{array}$ & $\begin{array}{c}.298^{* * * *} \\
(.057)\end{array}$ & $\begin{array}{c}-.223 * * * \\
(.043)\end{array}$ & $\begin{array}{c}-.218 * * * \\
(.046)\end{array}$ & $\begin{array}{c}-.290 * * * \\
(.046)\end{array}$ \\
\hline $\begin{array}{l}\text { Transition* } \\
\text { Resource } \\
\text { depletion/GNI }\end{array}$ & $\begin{array}{l}.192^{*} \\
(.105)\end{array}$ & $\begin{array}{l}.267 * * \\
(.117)\end{array}$ & $\begin{array}{c}.230 * * * \\
(.085)\end{array}$ & $\begin{array}{l}-.223^{*} \\
(.117)\end{array}$ & $\begin{array}{l}.135 * * \\
(.067)\end{array}$ & $\begin{array}{l}.130^{*} \\
(.069)\end{array}$ & $\begin{array}{l}.165^{* *} \\
(.072)\end{array}$ \\
\hline R-squared & .789 & .741 & .720 & .707 & .832 & .820 & .695 \\
\hline $\begin{array}{l}\text { F-statistic for } \\
\text { excl. instruments } \\
\text { (p-value) }\end{array}$ & - & - & - & $\begin{array}{l}18.65 \\
(.000)\end{array}$ & - & - & - \\
\hline Hansen J (p-value) & .785 & .435 & .923 & - & .633 & .492 & .398 \\
\hline Observations & 147 & 134 & 150 & 145 & 145 & 145 & 145 \\
\hline
\end{tabular}

Notes:

robust standard errors are in parentheses;

constant term and some of the independent variables coefficients (LAT, EUR, LATAM, EAST, MSLM, PRTS) are not shown;

*** - significant at 1\% level; ** - significant at 5\% level; * - significant at $10 \%$ level;

Excluded instruments: LAT, EAST (for Rule of law and Control of corruption); LAT, EUR (for Voice and accountability);

$1^{\text {st }}$ stage regressions for 1996 are not shown here because they are very similar to $1^{\text {st }}$ stage regressions for per capita GDP (column (5) in Table 3), although they are not identical due to the different number of observations in the regressions; $1^{\text {st }}$ stage regressions for 2005 are the same for all institutional variables;

Independent variables are measured for the same years as dependent variables 
Table 3A. Human capital investment regressions with per capita oil output value, 2000 and 2005 (IV GMM specifications)

Dependent variables: Logarithm of primary school enrollment, \% net; logarithm of secondary school enrollment, \% net, 2000 and 2005

\begin{tabular}{|c|c|c|c|c|c|}
\hline & \multicolumn{3}{|c|}{2000} & \multicolumn{2}{|c|}{2005} \\
\hline & $1^{\text {st }}$ stage & 2d stage & 2d stage & $2 d$ stage & $2 \mathrm{~d}$ stage \\
\hline Variable name & $\begin{array}{l}\text { GDP per } \\
\text { capita }\end{array}$ & $\begin{array}{l}\text { Prim. } \\
\text { school }\end{array}$ & $\begin{array}{c}\text { Sec. } \\
\text { school }\end{array}$ & $\begin{array}{l}\text { Prim. } \\
\text { school }\end{array}$ & $\begin{array}{c}\text { Sec. } \\
\text { school }\end{array}$ \\
\hline & (1) & (2) & (3) & (4) & (5) \\
\hline Per capita GDP & - & $\begin{array}{c}.261 * * * \\
(.041)\end{array}$ & $\begin{array}{c}.387 * * * \\
(.061)\end{array}$ & $\begin{array}{l}.141 * * * \\
(.026)\end{array}$ & $\begin{array}{c}.377^{* * *} \\
(.055)\end{array}$ \\
\hline Transition economy & $\begin{array}{c}-1.04 * * * \\
(.207)\end{array}$ & $\begin{array}{c}.285^{* * * *} \\
(.061)\end{array}$ & $\begin{array}{c}.445^{* * *} \\
(.107)\end{array}$ & $\begin{array}{c}.077 * * * \\
(.030)\end{array}$ & $\begin{array}{c}.303 * * * \\
(.103)\end{array}$ \\
\hline CIS & $\begin{array}{l}-.386 \\
(.434) \\
\end{array}$ & $\begin{array}{l}.146 \\
(.111)\end{array}$ & $\begin{array}{c}.551 * * * \\
(.108)\end{array}$ & $\begin{array}{c}.076 \\
(.055) \\
\end{array}$ & $\begin{array}{c}.509 * * * \\
(.127)\end{array}$ \\
\hline Per capita oil output & $\begin{array}{c}.128^{* * * *} \\
(.033)\end{array}$ & $\begin{array}{l}-.010 \\
(.009)\end{array}$ & $\begin{array}{l}-.001 \\
(.013)\end{array}$ & $\begin{array}{l}-.005 \\
(.005)\end{array}$ & $\begin{array}{l}-.003 \\
(.011)\end{array}$ \\
\hline Transition*PC oil output & $\begin{array}{l}-.047 \\
(.069)\end{array}$ & $\begin{array}{l}-.014 \\
(.020)\end{array}$ & $\begin{array}{l}-.021 \\
(.026)\end{array}$ & $\begin{array}{l}-.005 \\
(.010)\end{array}$ & $\begin{array}{l}-.018 \\
(.016)\end{array}$ \\
\hline R-squared & .682 & .405 & .784 & .356 & .770 \\
\hline $\begin{array}{l}\text { F-statistic for excl. instruments (p- } \\
\text { value) }\end{array}$ & $\begin{array}{l}14.14 \\
(.000)\end{array}$ & - & - & - & - \\
\hline Hansen J (p-value) & - & .406 & .546 & .310 & .156 \\
\hline Observations & 111 & 111 & 101 & 119 & 98 \\
\hline
\end{tabular}

Notes:

robust standard errors (bootstrapped standard errors with 50 replications in OLS regressions with predicted per capita GDP) are in parentheses;

constant term and some of the independent variables coefficients (LAT, EUR, LATAM, EAST, MSLM, PRTS) are not shown;

*** - significant at $1 \%$ level; ** - significant at $5 \%$ level; * - significant at $10 \%$ level;

Excluded instruments: LAT, LATAM;

$1^{\text {st }}$ stage regressions for the two human capital investment measures in 2000 are very similar, although they are not identical due to the different number of observations in the regressions. Column (1) shows $1^{\text {st }}$ stage regression for primary school enrollment. $1^{\text {st }}$ stage regressions for 2005 are not shown here because they are very similar to those in Column (4) of Table 2A, although they are not identical due to the different number of observations in the regressions;

Independent variables are measured for the same years as dependent variables 
Table 4A. Human capital investment regressions with share of resource depletion in GNI, 2000 and 2005 (IV GMM)

Dependent variables: Logarithm of primary school enrollment, \% net; logarithm of secondary school enrollment, \% net, 2000 and 2005

\begin{tabular}{|c|c|c|c|c|c|}
\hline & \multicolumn{3}{|c|}{2000} & \multicolumn{2}{|c|}{2005} \\
\hline & $1^{\text {st }}$ stage & 2d stage & 2d stage & 2d stage & 2d stage \\
\hline Variable name & $\begin{array}{l}\text { GDP per } \\
\text { capita }\end{array}$ & $\begin{array}{l}\text { Prim. } \\
\text { school }\end{array}$ & $\begin{array}{c}\text { Sec. } \\
\text { school }\end{array}$ & $\begin{array}{l}\text { Prim. } \\
\text { school }\end{array}$ & $\begin{array}{c}\text { Sec. } \\
\text { school }\end{array}$ \\
\hline & $(1)$ & (2) & (3) & (4) & (5) \\
\hline Per capita GDP & - & $\begin{array}{c}.232 * * * \\
(.037)\end{array}$ & $\begin{array}{c}.373^{* * * *} \\
(.054)\end{array}$ & $\begin{array}{c}.128 * * * * \\
(.025)\end{array}$ & $\begin{array}{c}.396^{* * *} \\
(.052)\end{array}$ \\
\hline Transition economy & $\begin{array}{l}-1.28 * * * \\
(.222)\end{array}$ & $\begin{array}{c}.317^{* * * *} \\
(.068)\end{array}$ & $\begin{array}{c}.453 * * * \\
(.115)\end{array}$ & $\begin{array}{l}.100 * * * \\
(.037)\end{array}$ & $\begin{array}{c}.332 * * * \\
(.107)\end{array}$ \\
\hline CIS & $\begin{array}{l}-.220 \\
(.450)\end{array}$ & $\begin{array}{l}.153 \\
(.105)\end{array}$ & $\begin{array}{l}.526 * * * \\
(.093)\end{array}$ & $\begin{array}{c}.075 \\
(.054)\end{array}$ & $\begin{array}{l}.507^{* * *} \\
(.126)\end{array}$ \\
\hline Resource depletion/GNI & $\begin{array}{l}.328 * * * \\
(.075)\end{array}$ & $\begin{array}{c}.004 \\
(.022)\end{array}$ & $\begin{array}{l}.037 \\
(.040)\end{array}$ & $\begin{array}{l}.016 \\
(.015)\end{array}$ & $\begin{array}{c}.004 \\
(.032)\end{array}$ \\
\hline $\begin{array}{l}\text { Transition* Resource } \\
\text { depletion/GNI }\end{array}$ & $\begin{array}{l}-.127 \\
(.158)\end{array}$ & $\begin{array}{l}-.055 \\
(.038)\end{array}$ & $\begin{array}{l}-.039 \\
(.063)\end{array}$ & $\begin{array}{l}-.040^{*} \\
(.022)\end{array}$ & $\begin{array}{l}-.047 \\
(.059)\end{array}$ \\
\hline R-squared & .711 & .511 & .788 & .440 & .779 \\
\hline $\begin{array}{l}\text { F-statistic for excl. instruments (p- } \\
\text { value) }\end{array}$ & $\begin{array}{l}15.74 \\
(.000)\end{array}$ & - & - & - & - \\
\hline Hansen J (p-value) & - & .481 & .495 & .769 & .166 \\
\hline Observations & 110 & 110 & 100 & 111 & 90 \\
\hline
\end{tabular}

Notes:

robust standard errors (bootstrapped standard errors with 50 replications in OLS regressions with predicted per capita GDP) are in parentheses;

constant term and some of the independent variables coefficients (LAT, EUR, LATAM, EAST, MSLM, PRTS) are not shown;

$* * *$ - significant at $1 \%$ level; ** - significant at 5\% level; * - significant at $10 \%$ level;

Excluded instruments: LAT, LATAM;

$1^{\text {st }}$ stage regressions for the two human capital investment measures are very similar, although they are not identical due to the different number of observations in the regressions. Column (1) shows $1^{\text {st }}$ stage regression for primary school enrollment. $1^{\text {st }}$ stage regressions for 2005 are not shown here because they are very similar to those in Column (4) of Table 2A, although they are not identical due to the different number of observations in the regressions;

Independent variables are measured for the same years as dependent variables 
Table 5A. Life expectancy and infant mortality regressions with per capita oil output value, 1995 and 2005 (IV GMM)

Dependent variables: Logarithm of life expectancy at birth, total (years); logarithm of infant mortality rate, under-5 (per 1000 births), 1995 and 2005

\begin{tabular}{|c|c|c|c|c|c|}
\hline & \multicolumn{3}{|c|}{1995} & \multicolumn{2}{|c|}{2005} \\
\hline & $1^{\text {st }}$ stage & 2d stage & 2d stage & 2d stage & 2d stage \\
\hline Variable name & $\begin{array}{c}\text { GDP per } \\
\text { capita }\end{array}$ & $\begin{array}{l}\text { Life } \\
\text { expect. }\end{array}$ & $\begin{array}{c}\text { Infant } \\
\text { mortality }\end{array}$ & $\begin{array}{c}\text { Life } \\
\text { expect. }\end{array}$ & $\begin{array}{c}\text { Infant } \\
\text { mortality }\end{array}$ \\
\hline & (1) & (2) & (3) & (4) & (5) \\
\hline Per capita GDP & - & $\begin{array}{c}.118^{* * * *} \\
(.015)\end{array}$ & $\begin{array}{c}-.850 * * * \\
(.102)\end{array}$ & $\begin{array}{l}.135^{* * *} \\
(.015)\end{array}$ & $\begin{array}{c}-.939 * * * \\
(.110)\end{array}$ \\
\hline Transition economy & $\begin{array}{c}-.908 * * * \\
(.213)\end{array}$ & $\begin{array}{c}.059 * * * \\
(.021)\end{array}$ & $\begin{array}{l}-.057 \\
(.105)\end{array}$ & $\begin{array}{l}.050^{* *} \\
(.022)\end{array}$ & $\begin{array}{l}-.129 \\
(.104)\end{array}$ \\
\hline CIS & $\begin{array}{l}-.331 \\
(.244)\end{array}$ & $\begin{array}{c}.085^{* * * *} \\
(.028)\end{array}$ & $\begin{array}{c}-.411 * * * \\
(.118)\end{array}$ & $\begin{array}{c}.042 \\
(.031)\end{array}$ & $\begin{array}{l}-.175 \\
(.165)\end{array}$ \\
\hline Per capita oil output & $\begin{array}{c}.181 * * * \\
(.031)\end{array}$ & $\begin{array}{c}-.010^{* *} \\
(.004)\end{array}$ & $\begin{array}{c}.082 * * * \\
(.029)\end{array}$ & $\begin{array}{c}-.014 * * * \\
(.005)\end{array}$ & $\begin{array}{c}.095 * * * \\
(.031)\end{array}$ \\
\hline Transition*PC oil output & $\begin{array}{l}-.148^{* *} \\
(.064)\end{array}$ & $\begin{array}{l}.000 \\
(.010)\end{array}$ & $\begin{array}{l}.012 \\
(.036)\end{array}$ & $\begin{array}{l}-.001 \\
(.009)\end{array}$ & $\begin{array}{l}-.008 \\
(.039)\end{array}$ \\
\hline R-squared & .662 & .773 & .884 & .664 & .814 \\
\hline $\begin{array}{l}\text { F-statistic for excl. instruments } \\
\text { (p-value) }\end{array}$ & $\begin{array}{l}41.48 \\
(.000)\end{array}$ & - & - & - & - \\
\hline Hansen J (p-value) & - & .082 & .565 & .946 & .818 \\
\hline Observations & 153 & 153 & 148 & 154 & 153 \\
\hline
\end{tabular}

Notes:

robust standard errors (bootstrapped standard errors with 50 replications in OLS regressions with predicted per capita GDP) are in parentheses;

constant term and some of the independent variables coefficients (LAT, EUR, LATAM, EAST, MSLM, PRTS) are not shown;

*** - significant at 1\% level; ** - significant at 5\% level; * - significant at $10 \%$ level;

Excluded instruments: LAT, EUR (life expectancy regressions) and LAT, LATAM (infant mortality regressions);

$1^{\text {st }}$ stage regressions for the two 1995 specifications are very similar, although not identical due to the different number of observations in the regressions. Column (1) shows $1^{\text {st }}$ stage regression for life expectancy. $1^{\text {st }}$ stage regressions for 2005 are not shown here because they are very similar to those in Column (4) of Table 2A, although they are not identical due to the different number of observations in the regressions;

Independent variables are measured for the same years as dependent variables 
Table 6A. Life expectancy and infant mortality regressions with share of resource depletion in GNI, 1995 and 2005 (IV GMM)

Dependent variables: Logarithm of life expectancy at birth, total (years); logarithm of infant mortality rate, under-5 (per 1000 births), 1995 and 2005

\begin{tabular}{|c|c|c|c|c|c|}
\hline & \multicolumn{3}{|c|}{1995} & \multicolumn{2}{|c|}{2005} \\
\hline & $1^{\text {st }}$ stage & 2d stage & 2d stage & 2d stage & 2d stage \\
\hline Variable name & $\begin{array}{c}\text { GDP per } \\
\text { capita }\end{array}$ & $\begin{array}{c}\text { Life } \\
\text { expect. }\end{array}$ & $\begin{array}{c}\text { Infant } \\
\text { mortality }\end{array}$ & $\begin{array}{c}\text { Life } \\
\text { expect. }\end{array}$ & $\begin{array}{c}\text { Infant } \\
\text { mortality }\end{array}$ \\
\hline & (1) & (2) & (3) & (4) & (5) \\
\hline Per capita GDP & - & $\begin{array}{l}.112^{* * *} \\
(.013)\end{array}$ & $\begin{array}{c}-.829 * * * \\
(.086)\end{array}$ & $\begin{array}{l}.109^{* * *} \\
(.014)\end{array}$ & $\begin{array}{c}-.955^{* * *} \\
(.118)\end{array}$ \\
\hline Transition economy & $\begin{array}{c}-1.13 * * * \\
(.220)\end{array}$ & $\begin{array}{c}.061 * * * \\
(.021)\end{array}$ & $\begin{array}{l}-.191 \\
(.126)\end{array}$ & $\begin{array}{l}.025 \\
(.021)\end{array}$ & $\begin{array}{l}-.196 \\
(.132)\end{array}$ \\
\hline CIS & $\begin{array}{l}-.196 \\
(.261)\end{array}$ & $\begin{array}{l}.070 * * \\
(.029)\end{array}$ & $\begin{array}{c}-.329 * * * \\
(.110)\end{array}$ & $\begin{array}{l}.030 \\
(.028)\end{array}$ & $\begin{array}{l}-.069 \\
(.168)\end{array}$ \\
\hline Resource depletion/GNI & $\begin{array}{c}.429 * * * \\
(.078)\end{array}$ & $\begin{array}{c}-.026^{* * *} \\
(.009)\end{array}$ & $\begin{array}{c}.186^{* * *} \\
(.056)\end{array}$ & $\begin{array}{l}-.011 \\
(.008)\end{array}$ & $\begin{array}{c}.187 * * * \\
(.056)\end{array}$ \\
\hline $\begin{array}{l}\text { Transition* Resource } \\
\text { depletion/GNI }\end{array}$ & $\begin{array}{c}-.374 * * * \\
(.134)\end{array}$ & $\begin{array}{l}.017 \\
(.018)\end{array}$ & $\begin{array}{l}-.019 \\
(.071)\end{array}$ & $\begin{array}{l}-.002 \\
(.015)\end{array}$ & $\begin{array}{l}-.042 \\
(.090)\end{array}$ \\
\hline R-squared & .679 & .775 & .893 & .695 & .856 \\
\hline $\begin{array}{l}\text { F-statistic for excl. instruments } \\
\text { (p-value) }\end{array}$ & $\begin{array}{l}58.27 \\
(.000) \\
\end{array}$ & - & - & - & - \\
\hline Hansen J (p-value) & - & .106 & .677 & .765 & .114 \\
\hline Observations & 150 & 150 & 145 & 145 & 144 \\
\hline
\end{tabular}

Notes:

robust standard errors (bootstrapped standard errors with 50 replications in OLS regressions with predicted per capita GDP) are in parentheses;

constant term and some of the independent variables coefficients (LAT, EUR, LATAM, EAST, MSLM, PRTS) are not shown;

$* * *$ - significant at $1 \%$ level; ** - significant at 5\% level; * - significant at $10 \%$ level;

Excluded instruments: LAT, EUR (life expectancy regressions) and LAT, LATAM (infant mortality regressions)

$1^{\text {st }}$ stage regressions for the two specifications are very similar, although not identical due to the different number of observations in the regressions. Column (1) shows $1^{\text {st }}$ stage regression for life expectancy. $1^{\text {st }}$ stage regressions for 2005 are not shown here because they are very similar to those in Column (4) of Table 2A, although they are not identical due to the different number of observations in the regressions;

Independent variables are measured for the same years as dependent variables 